\title{
MANAJEMEN LABA: PERAN KEAKTIFAN KOMITE AUDIT DAN AUDITOR EKSTERNAL BIG FOUR (STUDI EMPIRIS PADA PERUSAHAAN MANUFAKTUR YANG TERDAFTAR DI BEI 2013-2015)
}

\author{
Suci Rahmadani \\ Haryanto \\ Universitas Diponegoro Semarang \\ haryantogege@yahoo.com
}

\begin{abstract}
This study aims to determine: (1) the effect of activeness of the audit committee on earnings management, (2) the effect of external audit by Big Four on earnings management, (3) the effect of combination between activeness of the audit committee and external audit on earnings management. Audit committee and external audit have a very important role to oversee the financial reporting process and monitor the propensity of a company managers to manipulate earnings. Monitoring mechanism is a key factor to reduce conflict of interest and any opportunistic behavior from the manager. This study uses secondary data from annual reports and financial statements on manufacture companies listed on Indonesian Stock Exchange period 2013-2015 by using purposive sampling method. There are 67 companies samples or 201 observations that meet the criteria of the study sample. Analysis method in this research is Ordinary Least Square regression analysis. The results of this study indicate that the activeness of the audit committee indicate not significantly reduce earnings management. External audit by Big Four can decrease earnings management significantly. However, the combination activeness of the audit committee and external audit by Big Four indicate potential increase in earnings management significantly.
\end{abstract}

Keywords:

Earning management; audit committee; external audit by Big Four

PSAK No. 1 Paragraf ke 7 (Revisi 2009) merumuskan bahwa tujuan laporan keuangan adalah memberikan informasi mengenai posisi keuangan, kinerja keuangan dan arus kas entitas yang bermanfaat bagi sebagian besar pengguna laporan dalam pembuatan keputusan ekonomi. Penyajian laporan keuangan mendasarkan pada basis akrual. Akuntansi berbasis akrual dipilih dalam penyusunan laporan keuangan karena dianggap lebih mencerminkan kondisi perusahaan secara nyata karena metode pencatatan yang berdasarkan transaksi/kejadian. Manajemen memiliki fleksibilitas untuk memilih di antara beberapa cara alternatif dalam mencatat transaksi sekaligus memilih opsi-opsi yang ada dalam perlakuan akuntansi yang sama (Belkoui, 2009). Namun, fleksibilitas yang melekat dalam banyak standar akuntansi memfasilitasi manajemen untuk dapat mengambil keuntungan dari hal tersebut, sehingga dapat mengakibatkan biasan atas informasi yang sesungguhnya (Alves, 2013).

Akuntansi akrual dibagi menjadi dua yaitu discretionary accruals dan non-discretionary accruals. Discretionary accruals merupakan akrual yang dapat digunakan untuk memanajemen laba. Manajemen memiliki kekuatan untuk mengendalikan bagian akrual dalam jangka pendek (De angelo, 1989) dalam (Meutia, 2004). Non-discretionary accruals adalah komponen-komponen yang tidak dapat dikontrol oleh manajemen. Praktik akuntansi yang diterima umum memungkinkan timbulnya ketidakkonsistenan dalam pengukuran laba periodik dari perusahaan berbeda atau antar periode akuntansi yang sama (Chariri dan Ghozali, 2003). Manajemen dapat mengambil keuntungan dari prinsip akuntansi yang berlaku umum untuk memilih metode ketika menghitung laba dan langkah-langkah keuangan lainnya, yang dapat menyebabkan kualitas informasi keuangan menjadi rendah. Kebebasan pemilihan metode ini tentu saja menjadi celah bagi manajemen untuk 
mempercantik laporan keuangannya agar laba yang tercantum pada laporan keuangan sesuai dengan keinginan manajemen.

Laba akuntansi menyajikan informasi yang terkait dan memberikan manfaat bagi investor dalam melakukan keputusan pasar (Ball dan Brown, 1968). Manajemen wajib memberikan informasi yang terkait dengan aktivitas perusahaan kepada pemegang saham (shareholders) dan para pemangku kepentingan lainnya (stakeholders) dalam bentuk laporan keuangan (Baker dan AlThuneibat, 2009). Informasi laba dijadikan sebagai penentu keberhasilan manajemen dalam melakukan pengelolaan perusahaan dimata pemegang saham dan earning power perusahaan di masa depan. Earning power adalah kemampuan perusahaan untuk memperoleh laba dari modal investasikan setelah perusahaan melaksanakan semua kewajibannya. Adanya kecenderungan bahwa keputusan investor sangat dipengaruhi oleh informasi laba membuat manajemen melakukan tindakan menyimpang dengan melakukan manajemen laba.

Scott (2009) mendefinisikan manajemen laba sebagai kegiatan yang dilakukan untuk mempengaruhi besarnya laba yang akan dilaporkan melalui penentuan kebijakan akuntansi yang digunakan untuk tujuan tertentu. Manajemen laba merupakan tindakan manajemen untuk memaksimumkan atau meminimumkan laba yang dilaporkan dari unit yang menjadi tanggung jawabnya dan tidak memiliki hubungan terhadap perubahan profitabilitas perusahaan dalam jangka panjang (Copeland, 1968) dalam (Utami, 2005). Manajemen laba merupakan tindakan yang dilakukan manajemen untuk meningkatkan laba dengan cara melakukan treatment komponen discretionary accruals pada laporan keuangan (Sugiri, 1998) dalam (Pratiwi dan Purnomo, 2009). Manajemen laba banyak dilakukan oleh pihak manajemen dalam rangka meningkatkan kompensasi dan job security (Healy dan Wahlen, 1999) dalam (Murhadi, 2009). Walaupun tindakan manajemen laba tidak bertentangan dengan prinsip-prinsip akuntansi yang berterima umum namun tindakan ini dapat mempengaruhi kualitas dari laporan keuangan.

Manajemen laba terjadi karena adanya pemisahan kewenangan dan kepentingan antara shareholders (prinsipal) dan manajemen (agen) yang akan menimbulkan konflik agensi. Konflik agensi merupakan konflik antara pemegang saham (shareholders) dengan manajemen dimana pihak manajemen selaku agen dalam menjalankan perannya tidak sejalan dengan kepentingan prinsipal yang akan bermuara pada kinerja perusahaan. Alves (2013) berpendapat bahwa masalah keagenan tersebut timbul sebagai akibat dari sifat oportunistik manajemen (agen) yang cenderung untuk lebih mengutamakan kesejahteraannya yang bertentangan dengan tujuan prinsipal. Masalah keagenan potensial terjadi apabila bagian kepemilikan manajemen atas saham perusahaan kurang dari seratus persen (Masdupi, 2012). Dengan proporsi kepemilikan yang hanya sebagian maka akan semakin mendorong manajemen untuk mengambil tindakan yang hanya menguntungkan dirinya sendiri bukannya memaksimalkan kinerja perusahaan.

Terkuaknya kasus Enron dan keterlibatan KAP Enderson menyebabkan tereduksinya kepercayaan publik akan tata kelola perusahaan. Kasus ini turut menyita perhatian pemerintah Amerika Serikat yang berimplikasi pada diterbitkannya Sarbanes-Oxley Act (SOX) yang bertujuan untuk mengembalikan kepercayaan publik pasca skandal yang dilakukan oleh Enron. SarbanesOxley Act mendasari terbentuknya Public Company Accounting Oversight Board (PCAOB) yang bertugas untuk menetapkan standar bagi auditor eksternal perusahaan publik. PACOB juga bertugas untuk melakukan pengawasan, pengaturan dan mendisiplinkan kantor-kantor akuntan publik dengan ruang lingkup mengenai tata kelola perusahaan, independensi auditor, tata kelola perusahaan, penilaian pengendalian internal, dan pelaporan laporan keuangan. Dalam SarbanesOxley Act (SOX) Section 301 perusahaan diwajibkan untuk memiliki komite audit independen yang bertugas untuk memilih, menentukan kompensasi, dan melakukan pengawasan kepada auditor eksternal. Di Indonesia keberadaan komite audit wajib dimiliki perusahaan publik, hal tersebut dipertegas dengan adanya peraturan yang dikeluarkan oleh Bursa Efek Indonesia pada tahun 2004 yang mewajibkan setiap perusahaan yang tercatat di Bursa Efek Indonesia untuk memiliki komite audit. Peraturan yang dikeluarkan BEI diperkuat dengan adanya surat edaran yang dikeluarkan Badan Pengawas Pasar Modal (Bapepam) Nomor SE-03/PM/2000 mengenai perlunya komite audit 
dimiliki oleh setiap emiten. Keputusan Ketua Badan Pengawas Pasar Modal dan Lembaga Keuangan Nomor Kep-643/BL/2012 mengenai pembentukan dan pedoman pelaksanaan kerja komite audit. Penerbitan peraturan ini diharapkan dapat meningkatkan independensi, peran serta kewenangan Komite Audit dalam membantu pelaksanaan fungsi dan tugas pengawasan dewan komisaris perusahaan publik atas kinerja perusahaan.

Komite Audit sebagai pihak internal yang melakukan pengawasan terhadap kredibilitas laporan keuangan maka diperlukan juga pengawasan dari pihak eksternal dalam hal ini auditor eksternal. Menurut Halim (2008) komite audit dapat berperan sebagai penghubung antara auditor dan manajemen. Secara luas diketahui bahwa komite audit dan auditor eksternal memainkan peran utama dalam memastikan integritas dari laporan keuangan (Cohen, 2004). Tingginya kualitas audit yang dilakukan oleh auditor eksternal dan komite audit berhubungan dengan tingginya kualitas laba (Becker, 1998). Penggunaan KAP Big Four sebagai auditor eksternal dianggap dapat meningkatkan kredibilitas laporan keuangan. Hasil penelitian yang dilakukan Saleh et al. (2007) menunjukkan perusahaan yang menggunakan jasa dari KAP Big Six (sekarang Big Four) lebih sedikit menggunakan discretionary accrual dibandingkan perusahaan yang menggunakan jasa KAP Non-Big Six.

Maraknya praktik manajemen laba yang terjadi mendorong manajemen untuk menerapkan Good Corporate Governance yang bertujuan untuk meminimalkan praktik manajemen laba yang terjadi di perusahaan. Salah satu cara untuk meminimalkan praktik manajemen laba yaitu dengan dibentuknya komite audit. Keberadaan komite audit diharapkan dapat memberikan pengawasan terhadap manajamen sehubungan dengan pengendalian internal dan manajemen serta pelaporan keuangan. Selain itu, pemilihan KAP Big Four dianggap dapat memperkecil praktik manajemen laba serta dapat meningkatkan kredibilitas dari laporan keuangan.

Penelitian ini bertujuan untuk menguji pengaruh keaktifan komite audit, auditor eksternal Big Four terhadap praktik manajemen laba serta kombinasi pengaruh komite audit dan auditor eksternal Big Four terhadap praktik manajemen laba dengan variabel kontrol ROA, leverage, ukuran perusahaan dan ukuran dewan komisaris.

Teori keagenan (agency theory) menjelaskan hubungan atau kontraktual antara prinsipal dan agen. Prinsipal adalah pihak yang mempekerjakan agen untuk melakukan tugas dalam rangka memenuhi kepentingan prinsipal, sedangkan agen adalah pihak yang menjalankan kepentingan prinsipal (Scott, 2009). Dalam dunia bisnis/perusahaan, prinsipal adalah shareholders (pemegang saham) yang melimpahkan wewenangnya kepada manajemen (agen) untuk melakukan pengelolaan perusahaan yang dimilikinya. Adanya pemisahan kewenangan dan kepentingan antara pemegang saham (prinsipal) dan manajemen (agen) tersebut akan menimbulkan masalah keagenan (agency problem).

Perbedaan tujuan antara pemegang saham (prinsipal) dengan manajemen (agen) dapat menyebabkan terjadinya conflict of interest dan asyimetric information. Conflict of interest adalah konflik yang terjadi karena tidak sejalannya tujuan yang dimiliki antara agen dan prinsipal sehingga dalam melaksanakan tugasnya agen bertindak tidak sesuai dengan kepentingan prinsipal. Asymmetric information merupakan ketidakseimbangan antara informasi yang dimiliki oleh agen dan prinsipal dalam pengelolaan perusahaan (Ujiyantho dan Pramuka, 2007). Asymetric information terjadi dimana manajemen secara umum memiliki lebih banyak informasi mengenai posisi keuangan yang sebenarnya dan posisi operasi entitas perusahaan (Messier, 2005). Menurut Scott (2009) terdapat dua tipe asymetric information yaitu: adverse selection dan Moral hazard. Adverse selection yaitu manajemen selaku agen mengetahui lebih banyak informasi, keadaan, dan prospek perusahaan dibanding pemilik. Selain itu fakta yang mungkin akan mempengaruhi pengambilan keputusan pemegang saham tidak disampaikan kepada pemegang saham, sedangkan moral hazard merupakan kondisi dimana aktivitas yang dilakukan manajemen tidak seluruhnya diketahui oleh pemegang saham. Adanya asymmetric information tersebut memberi peluang bagi manajemen untuk melakukan tindakan manajemen laba (Richardson, 2000).

Dalam mengatasi masalah keagenan ini akan menimbulkan biaya yang disebut agency cost. 
Agency cost adalah jumlah dari biaya yang dikeluarkan prinsipal untuk melakukan pengawasan terhadap agen (Jensen dan Meckling, 1976). Biaya untuk pengawasan ini digunakan untuk mempekerjakan auditor eksternal yang bertugas untuk mengaudit laporan keuangan yang disajikan oleh manajemen. Penggunaan jasa auditor eksternal yang ditugaskan untuk mengaudit laporan keuangan merupakan salah satu upaya terbaik untuk mengurangi dan mengatasi masalah keagenan yang timbul (Hendriksen dan Brenda, 1992).

\section{Manajemen Laba}

Scott (2003) mendefinisikan manajemen laba sebagai "the choice by a manager of accounting policies so as to achive some" yang artinya pilihan manajemen dalam menerapkan kebijakan akuntansi yang digunakan untuk mencapai tujuan tertentu. Scott (2003) menjelaskan terdapat beberapa motivasi yang mendorong manajemen melakukan praktik manajemen laba, antara lain motivasi bonus, kontrak, politik, pajak, pergantian CEO, IPO, pasar modal. Sistem penggajian yang berdasarkan bonus mendorong manajemen untuk meningkatkan kinerjanya dimata shareholders, dimana ukuran kinerja dari seorang manajemen dinilai dari laba yang dihasilkannya. Motivasi kontrak berhubungan dengan perjanjian utang jangka panjang. Dimana manajemen berusaha untuk menaikkan laba bersih dengan tujuan untuk menghindari kemungkinan terjadinya wanprestasi. Motivasi politik berkaitan dengan hubungan antara perusahaan dengan pemerintah, perusahaan cenderung memilih metode akuntansi yang dapat menurunkan laba. Hal ini dilakukan karena aktivitas perusahaan berhubungan dengan kebutuhan masyarakat secara umum sehingga cenderung mendapatkan pengawasan yang ketat dari pemerintah. Pajak yang dibayarkan perusahaan berbanding lurus dengan laba yang dihasilkan perusahaan. Semakin tinggi laba yang dihasilkan maka pajak yang dibayarkan akan semakin besar begitupun sebaliknya. CEO yang akan pensiun cenderung untuk meningkatkan laba yang berimplikasi dengan peningkatan bonus yang diterima CEO. Perusahaan yang akan melakukan penawaran saham perdana (IPO) berusaha untuk menaikkan laba dengan tujuan agar mendapatkan respon positif dari pasar dan menaikkan harga saham.

Menurut Scott (2003) terdapat beberapa pola yang seringkali dilakukan manajemen dalam praktik manajemen laba yaitu antara lain taking a bath, income minimization, income maximization, income smoothing. Terjadinya taking a bath pada umumnya dilakukan pada stress period atau reorganisasi termasuk pengangkatan CEO baru. Jika perusahaan wajib melaporkan laba yang tinggi maka manajemen berusaha untuk melaporkan laba yang tinggi juga. Laba yang tinggi diperoleh manajemen dengan cara menghapus aset dengan harapan laba yang akan datang dapat meningkat. Praktik ini mengakui biaya pada periode yang akan datang sebagai kerugian pada periode berjalan. Income minimization, pola ini hampir sama dengan taking a bath, tetapi lebih sedikit berbahaya, yakni dilakukan sebagai alasan politis pada periode laba yang tinggi dengan mempercepat penghapusan aset tetap dan aset tak berwujud dan mengakui pengeluaranpengeluaran sebagai biaya. Pada saat profitabilitas perusahaan sangat tinggi dengan maksud agar tidak mendapat perhatian secara politis, kebijakan yang diambil dapat berupa penghapusan atas barang modal dan aset tak berwujud, biaya iklan dan pengeluaran untuk penelitian dan pengembangan hasil akuntansi untuk biaya eksplorasi. Income maximization, pola ini bertujuan agar net income yang dilaporkan tinggi agar bonus yang diperoleh lebih besar juga. Sistem pembayaran bonus yang didasarkan pada informasi akuntasi mendorong manajemen untuk memanipulasi informasi akuntansi yang bertujuan untuk menaikkan laba sehingga bonus tahunan yang dibayarkan semakin besar. Tindakan ini biasa dilakukan ketika perusahaan dalam kondisi yang kurang baik sehingga laba yang dihasilkan mengalami penurunan. Income smoothing, pola income smoothing merupakan salah satu yang paling menarik. Pola ini dilakukan dengan cara melakukan pemerataan laba yang dilaporkan untuk tujuan pelaporan eksternal. Pola ini biasanya dikhususkan untuk investor karena investor cenderung menyukai laba yang relatif stabil. 


\section{Pengembangan Hipotesis}

Mengacu pada teori agensi, pihak pemegang saham (prinsipal) akan selalu tertarik pada pencapaian laba yang dihasilkan oleh pihak manajemen selaku agen (Hendriksen dan Brenda, 1992). Manajemen berkewajiban untuk mempertanggungjawabkan kinerja mereka sesuai dengan yang diamanatkan oleh prinsipal. Namun dalam proses perjalanan sering terjadi ketidakseimbangan informasi yang dimiliki antara pihak manajemen dan pemegang saham hal tersebut dikarenakan pihak manajemen yang melakukan pengelolaan terhadap perusahaan sehingga lebih mengetahui kondisi perusahaan sesungguhnya. Selain itu, seringkali terjadi ketidakselarasan tujuan yang dimiliki antara agen dan prinsipal dalam melaksanakan tugasnya. Hal inilah yang mendorong pihak manajemen sering kali melakukan praktik manajemen laba.

Praktik manajemen laba dianggap dapat mengurangi kualitas laporan keuangan yang disajikan yang akan berimplikasi pada kesalahan pengambilan keputusan oleh pengguna laporan keuangan. Untuk mengurangi praktik manajemen laba yang terdapat di perusahaan diperlukan struktur good corporate governance. Peran struktur good corporate governance bertujuan untuk memastikan kepatuhan terhadap sistem akuntansi keuangan dan untuk menjaga kredibilitas laporan keuangan. Untuk menjamin kredibilitas suatu laporan keuangan diperlukan mekanisme pengawasan dalam perusahaan. Mekanisme pengawasan dalam suatu perusahaan umumnya dilakukan oleh komite audit selaku pihak internal perusahaan dan audit eksternal sebagai pihak eksternal.

Komite audit berfungsi untuk melakukan proses pengawasan pelaporan keuangan dan memantau manajemen dalam melakukan kecenderungan tindakan memanipulasi laba (Alves, 2013). Tugas yang dilakukan komite audit berhubungan dengan penelaahan atas informasi laporan keuangan serta ketaatan terhadap peraturan perundang-undangan yang berhubungan dengan kegiatan perusahaan. Komite audit merupakan perwakilan dari pihak pemegang saham, sehingga komite audit akan berupaya untuk melakukan perlindungan terhadap kepentingan pemegang saham. Jika terdapat penyimpangan yang dilakukan oleh pihak manajemen maka komite audit akan melaporkannya kepada pemegang saham.

Pengawasan dari pihak eksternal juga diperlukan dalam mengurangi praktik manajemen laba, dimana kinerja audit eksternal yang independen dapat melaporkan praktik manajemen laba. Bentuk pengawasan ini dilakukan oleh audit eksternal dengan cara membantu dewan komisaris dalam menjalankan tanggung jawabnya terutama dengan masalah yang berhubungan dengan kebijakan akuntansi perusahaan, pengawasan internal, dan sistem pelaporan keuangan karena auditor eksternal akan memberikan opini keuangan secara independen.

\section{Keaktifan Komite Audit dan Praktik Manajemen Laba}

Komite audit merupakan sub-komite yang dibentuk oleh dewan komisaris yang salah satu tujuannya untuk memediasi komunikasi formal antara dewan komisaris, manajemen dan auditor eksternal. Adanya komunikasi formal antara dewan komisaris, manajemen dan auditor eksternal akan menjamin proses audit internal dan audit eksternal dapat terlaksana dengan baik. Proses audit internal dan audit eksternal yang dilaksanakan dengan baik akan berdampak pada peningkatan akurasi laporan keuangan dan kemudian akan meningkatkan kepercayaan para pemangku kepentingan terhadap kualitas laporan keuangan (Anderson et al., 2003) dalam (Suaryana, 2007), Chandrasegar (2013), Putri (2014), Hermitasari (2016).

Komite audit memiliki fungsi tata kelola perusahaan yang penting untuk digunakan sebagai acuan dalam memberikan saran mengenai operasional dan regulasi (Menon dan Williams, 1994). Komite audit dianggap sebagai seperangkat mekanisme pengawasan yang dapat membantu mengurangi masalah agensi yang ada pada perusahaan dengan cara mengurangi asimetris informasi yang terjadi antara pihak manajemen dengan pemangku kepentingan lainnya (Chen et al., 2008).

Komite audit merupakan bentuk delegasi dari dewan komisaris yang bertujuan untuk melakukan perlindungan terhadap kepentingan pemegang saham (Klien, 1998). Pendelegasian tanggung jawab itu berupa pemantauan laporan keuangan tahunan agar lebih relevan dan memiliki 
realibilitas. Menurut Defond dan Jiambalvo (1991), komite audit dianggap dapat meningkatkan kualitas dan akurasi informasi dari laporan keuangan melalui pengawasan dan kontrol yang lebih ketat atas karyawan dan petugas yang bertanggung jawab membuat dan melaporkan laporan tersebut. Sehingga dapat disimpulkan bahwa komite audit berperan penting dalam mereduksi terjadi praktik manajemen laba yang berimplikasi pada peningkatan kualitas laba.

Salah satu cara komite audit dalam melaksanakan fungsi pengawasannya yaitu dengan cara melakukan pertemuan dengan sesama anggota komite (Saleh et al,. 2007). Frekuensi pertemuan rutin yang dilakukan antar anggota komite audit diharapkan mampu mengurangi tingkat manajemen laba (Pamudji dan Trihartati, 2008). Berdasarkan surat keputusan Bapepam LK Nomor Kep-643/BL/2012 tentang Pembentukan dan Pedoman Pelaksanaan Kerja Komite Audit menyebutkan bahwa komite audit harus mengadakan rapat secara berkala paling kurang satu kali dalam tiga bulan atau empat kali dalam setahun. Frekuensi pertemuan yang dilakukan oleh komite audit dalam satu tahun dapat dijadikan acuan untuk melihat keaktifan dari komite audit suatu perusahaan. Menon dan Williams (1994) menyatakan bahwa komite audit yang tidak aktif atau hanya melakukan sedikit pertemuan maka tidak melakukan pengawasan secara efektif. Komite audit yang aktif bertemu secara teratur untuk memastikan bahwa proses pelaporan keuangan berjalan dengan baik. Semakin tinggi jumlah pertemuan yang diadakan komite audit maka semakin aktif komite audit menjalankan tugas, peran dan tanggung jawabnya, sehingga diharapkan dapat lebih meningkatkan kegiatan pemantauan manajemen dan mencegah praktik manajemen laba.

Beberapa hasil penelitian menunjukkan bahwa keaktifan komite audit berpengaruh terhadap praktik manajemen laba (Saleh et al., 2007). Penelitian Xie et al. (2003) menemukan bahwa jumlah pertemuan komite audit berhubungan negatif dengan discretionary accruals. Hasil penelitian Xie et al. (2003) mengindikasikan semakin besarnya pertemuan komite audit maka akan menurunkan manajemen laba. Selain itu, hasil penelitian ini juga menunjukkan bahwa komite audit yang aktif melakukan pertemuan dapat berimplikasi pada pengawasan yang lebih baik.

H1: Keaktifan komite audit berpengaruh negatif terhadap praktik manajemen laba

\section{Auditor Eksternal Big Four dan Praktik Manajemen Laba}

Audit eksternal atau lebih umum disebut auditor independen bertanggung jawab untuk melakukan fungsi pengauditan atas laporan keuangan yang diterbitkan oleh perusahaan (Jusup, 2001). Audit eksternal bertujuan untuk memberikan jaminan tentang kualitas dan kredibilitas informasi keuangan suatu perusahaan. Auditor memberikan dua peran penting bagi pelaku pasar modal yaitu peran informasi dan peran asuransi. Peran ini diperoleh karena auditor memberikan verifikasi yang independen dari laporan keuangan yang disiapkan oleh manajemen serta kualitas dari hasil audit akan memberikan kontribusi terhadap kredibilitas dari laporan keuangan tersebut sedangkan kualitas audit tergantung pada kompetensi dan independensi yang dimiliki auditor (Becker et al., 1998; Ahadiat, 2011).

Penelitian kualitas audit difokuskan pada ukuran jasa audit eksternal yang digunakan. Alasan yang mendasari pembedaan ini karena audit eksternal yang besar dalam hal ini auditor eksternal Big Four memiliki insentif yang lebih baik dalam mendeteksi dan mengungkapkan kesalahan pelaporan yang dilakukan manajemen karena klien dapat lebih efektif dipantau oleh auditor eksternal Big Four dan mereka memiliki lebih banyak risiko ketika terjadi kegagalan audit (Bauwhede et al., 2003). Sehingga mereka melindungi reputasinya melalui penghindaran tanggung jawab hukum (Behn et al., 1997). Auditor eksternal Big Four akan lebih konservatif dalam menahan klien menggunakan discretionary accruals. Beberapa penelitian lain menunjukkan bahwa auditor dengan kualitas yang lebih tinggi dapat mengurangi tingkat akrual manajemen laba (Becker et al., 1998; Krishnan, 2003; Lin \& Hwang, 2010).

Becker et al. (1998) meneliti pengaruh kualitas audit terhadap manajemen laba. Hasil penelitiannya menunjukkan bahwa auditor eksternal Big Six (sekarang Big four) memiliki kualitas yang lebih tinggi dibanding auditor eksternal Non-Big Six. Selain itu, penelitian ini juga menunjukkan bahwa kualitas audit yang tinggi berkaitan dengan kurangnya fleksibilitas akuntansi. 
Francis et al. (1999) menemukan bahwa perusahaan yang diaudit oleh auditor eksternal Big Six memiliki jumlah discretionary accrual yang lebih rendah daripada perusahaan yang diaudit oleh auditor eksternal Non-Big Six. Penelitian yang dilakukan Alves (2013) menemukan bahwa perusahaan yang diaudit oleh auditor eksternal Big Four memiliki tingkat praktik manajemen laba yang lebih rendah dibandingkan dengan perusahaan yang diaudit oleh auditor eksternal Non-Big Four.

H2: Auditor Eksternal Big Four berpengaruh negatif terhadap praktik manajemen laba.

\section{Kombinasi Keaktifan Komite Audit dan Auditor Eksternal Big Four dengan Praktik Manajemen Laba}

Keaktifan komite audit dan audit eksternal merupakan faktor penting yang efektif dalam meningkatkan pengawasan, akuntabilitas dan tata kelola perusahaan. Komite audit berfungsi untuk mengawasi proses pelaporan keuangan dan memantau kecenderungan manajemen dalam melakukan praktik manajemen laba. Selain itu, komite audit bertugas untuk memberikan rekomendasi kepada dewan komisaris dalam hal pemilihan jasa audit eksternal yang akan mereka gunakan. Dalam melaksanakan proses jasa audit eksternal, komite audit wajib untuk turut berperan aktif dalam hal memberikan persetujuan rencana kegiatan dan program kegiatan yang akan dijalankan.

Audit eksternal berperan dalam memberikan opini audit mengenai kewajaran laporan keuangan auditan, dalam semua hal yang material, yang didasarkan atas kesesuaian penyusunan laporan keuangan dengan prinsip akuntansi berterima umum (Mulyadi, 2009). Keberadaan komite audit dan audit eksternal bersama-sama bertugas untuk melakukan pengawasan untuk memastikan dan meningkatkan kredibilitas dan validitas suatu laporan keuangan. Mekanisme pengawasan yang dilakukan oleh komite audit ataupun audit eksternal tidak dapat dilakukan secara independen dan terpisah karena kedua aktivitas pemantauan ini merupakan suatu kesatuan dalam struktur good corporate governance.

Komite audit memiliki hubungan yang erat dengan audit eksternal. Komite audit bertugas untuk memberikan rekomendasi kepada dewan direksi dalam hal penentuan penggunaan jasa auditor. Komite audit harus bertemu dengan auditor eksternal sebelum perikatan dimulai untuk membahas tanggung jawab auditor dan kebijakan akuntansi signifikan serta memberikan masukan terbatas tentang persetujuan rencana tindakan, program kegiatan, dan lingkup pekerjaan auditor (Messier, 2005). Selain itu, komite audit menjadi penerima pertama laporan audit dan komite audit harus menjadi rekan bagi auditor eksternal dalam perusahaan. Laporan audit yang telah diterima oleh komite audit kemudian dibandingkan dengan laporan internal perusahaan.

Komite audit dapat berperan menjadi pihak penengah jika terjadi perbedaan pendapat antara manajemen dengan auditor mengenai penerapan prinsip akuntansi yang berlaku umum. Komposisi komite audit yang terdiri dari anggota yang independen serta memiliki pengetahuan dalam bidang keuangan dan akuntansi cenderung mendukung opini yang diberikan auditor eksternal.

Auditor eksternal memegang peranan penting dalam memberikan kredibilitas independen untuk laporan keuangan yang diterbitkan dan digunakan oleh pemangku kepentingan sebagai dasar untuk membuat alokasi keputusan ekonomi. Oleh karena itu, komite audit dan auditor eksternal memiliki dorongan untuk menerbitkan laporan kualitas tinggi. Selain itu, komite audit dan auditor eksternal diharapkan untuk melakukan pekerjaan audit kualitas tinggi yang bertujuan untuk menjaga reputasi dan menghindari tanggung jawab hukum.

H3: Kombinasi antara keaktifan komite audit dan auditor eksternal Big Four berpengaruh negatif terhadap praktik manajemen laba 


\section{METODE}

\section{Variabel Penelitian dan Definisi Operasional Variabel}

Dalam penelitian ini variabel dependen adalah manajemen laba. Variabel manajemen laba dalam penelitian ini akan menggunakan discretionary accruals sebagai proksi dengan jones modified yang disarankan oleh Dechow et al (1995). Variabel independen yang digunakan adalah keaktifan komite audit, audit eksternal, dan kombinasi dari kedua variabel keaktifan komite audit dan audit eksternal. Variabel kontrol yang digunakan pada penelitian ini adalah ROA, leverage, size, dan ukuran dewan komisaris.

Tabel 1

Variabel, Jenis, Indikator, dan Skala Pengukuran

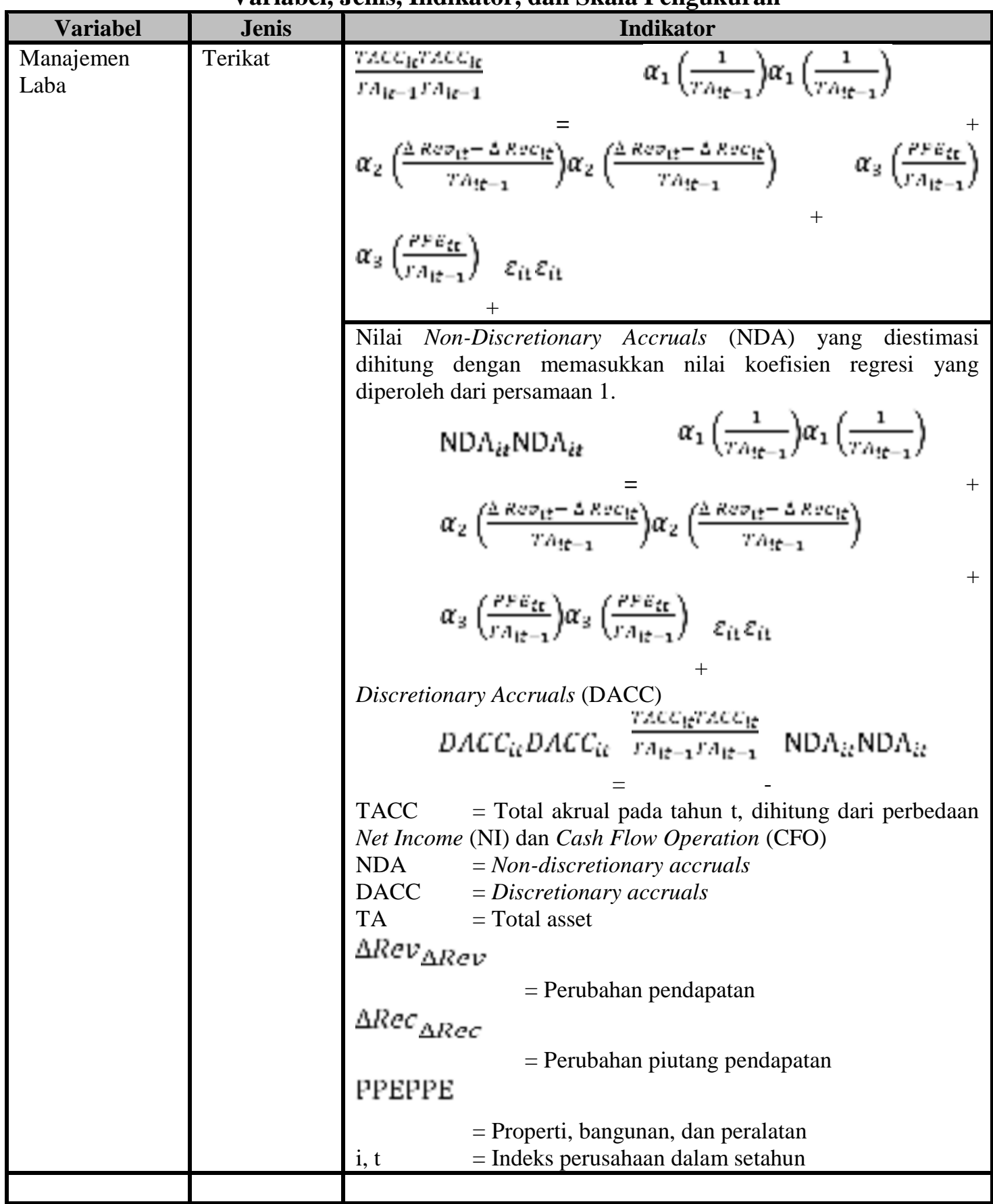




\begin{tabular}{|l|l|l|}
\hline \multicolumn{1}{|c|}{ Variabel } & \multicolumn{1}{|c|}{ Jenis } & \multicolumn{1}{c|}{ Indikator } \\
\hline Keaktifan & Bebas & $\begin{array}{l}\text { Jumlah Pertemuan komite audit dalam satu tahun dengan } \\
\text { menggunakan variabel dummy,1 jika jumlah pertemuan diatas } \\
\text { nilai median dan 0 sebaliknya. Jika pertemuan Komite Audit 4 } \\
\text { kali atau lebih dalam setahun maka dikategorikan aktif sedangkan } \\
\text { dibawah 4 kali pertemuan dalam setahun dikategorikan tidak } \\
\text { aktif. }\end{array}$ \\
\hline Audit Eksternal & Bebas & $\begin{array}{l}\text { Menggunakan variabel dummy, 1 jika diaudit KAP Big Four dan } \\
\text { 0 sebaliknya. } \\
\text { (1) } \begin{array}{l}\text { KAP PricewaterhouseCoopers, yang bekerjasama dengan } \\
\text { KAP Drs. Haryanto Sahari dan Rekan, KAP Tanudiredja, }\end{array} \\
\text { Wibisana, dan Rintis dan Rekan. } \\
\text { KAP Deloitte Touche Tohmatsu, yang bekerjasama dengan } \\
\text { KAP Drs. Hans Tuanokata dan Mustofa, Osman Bing Satrio } \\
\text { dan Eny. }\end{array}$ \\
& & $\begin{array}{l}\text { KAP Ernst \& Young, yang bekerjasama dengan KAP } \\
\text { Purwantono, Suherman, dan Surja. } \\
\text { KAP KPMG (Klynveld Peat Marwick Goerdeler), yang } \\
\text { bekerjasama dengan KAP Sidharta-Sidharta dan Widjaja. }\end{array}$ \\
\hline ROA & Kontrol & Laba bersih dibagi total aset \\
\hline Leverage & Kontrol & Utang dibagi aset \\
\hline $\begin{array}{l}\text { Ukuran } \\
\text { Perusahaan }\end{array}$ & Kontrol & Nilai pasar perusahan \\
\hline $\begin{array}{l}\text { Ukuran Dewan } \\
\text { Komisaris }\end{array}$ & Kontrol & Jumlah anggota komisaris \\
\hline
\end{tabular}

\section{Populasi dan Sampel}

Populasi yang digunakan dalam penelitian ini adalah seluruh perusahaan manufaktur yang terdaftar dalam Bursa Efek Indonesia (BEI) tahun 2013-2015. Metode penentuan sampel yang digunakan adalah purposive sampling. Kriteria penentuan sampel yang digunakan dalam penelitian ini adalah sebagai berikut: (1) menerbitkan laporan keuangan yang telah diaudit pada tahun 2013, 2014, dan 2015 (2) menerbitkan annual report pada tahun 2013, 2014, dan 2015 (3) menyajikan laporan tata kelola perusahaan dalam laporan tahunannya (4) menyajikan data tentang frekuensi pertemuan komite audit dan (5) menyajikan informasi tentang audit eksternal.

\section{Metode Analisis dan Uji Hipotesis}

Penelitian ini menggunakan metode analisis Ordinary Least Square Regression (Regresi OLS) untuk pengujian hipotesis. Model regresi OLS yang digunakan pada penelitian ini adalah sebagai berikut:

$$
\begin{gathered}
D A C C_{i t}=\beta_{0}+\beta_{1}\left(A C C_{i t}\right)+\beta_{2}\left(\Delta E_{i t}\right)+\beta_{3}\left(A C C A E_{i t}\right)+\beta_{1}\left(R O A_{i t}\right)+\beta_{5}\left(L e v_{i t}\right) \\
+\beta_{i}\left(\text { Size }_{i t}\right)+\beta_{7}\left(\text { Board }_{i t}\right)+\varepsilon_{i t}
\end{gathered}
$$

Keterangan:

TACC $=$ Discretionary accruals perusahaan yang diperkirakan dari model modified Jones

ACC $=$ Keaktifan komite audit yang diukur berdasarkan jumlah rapat komite audit selama satu tahun. Nilai 1 jika komite audit dikategorikan aktif (jumlah rapat komite audit dalam satu tahun berada diatas nilai median) dan 0 jika sebaliknya

$\mathrm{AE} \quad=$ Penggunaan audit eksternal dalam suatu perusahaan. Diberi nilai 1 jika perusahaan menggunakan jasa KAP Big Four dan diberi nilai 0 jika sebaliknya

AAC_AE $=$ Kombinasi antara keaktifan komite audit dan keberadaan audit eksternal dalam suatu perusahaan. Diberi nilai 1 jika jumlah rapat komite audit dalam satu tahun diatas nilai median dan perusahaan menggunakan jasa KAP Big Four sebagai audit eksternalnya. Diberi nilai 0 jika perusahaan tidak 


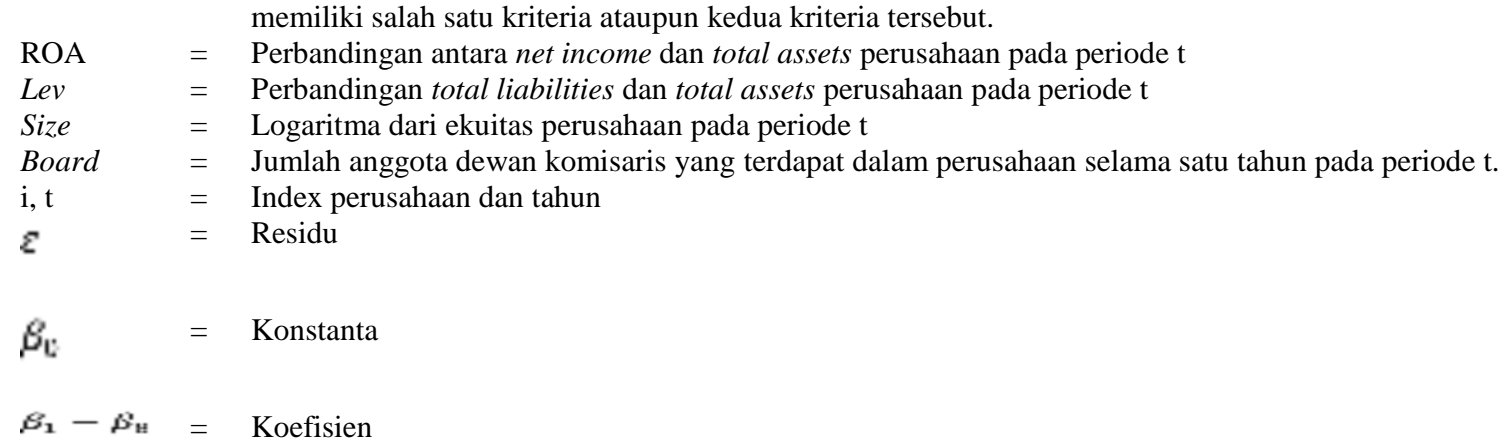

\section{HASIL DAN PEMBAHASAN}

\section{Deskripsi Objek Penelitian}

Penelitian ini menggunakan populasi perusahaan yang listed di Bursa Efek Indonesia tahun 2013, 2014, dan 2015. Sampel penelitian menggunakan perusahaan yang listed di Bursa Efek Indonesia yang bergerak dalam sektor manufaktur. Perincian perolehan sampel penelitian dapat dilihat pada tabel 4.1 sebagai berikut:

Tabel 2

Sampel Penelitian Periode 2013-2015

\begin{tabular}{|l|c|}
\hline \multicolumn{1}{|c|}{ Kriteria Sampel } & $\begin{array}{c}\text { Jumlah } \\
\text { Perusahaan }\end{array}$ \\
\hline Perusahaan manufaktur yang terdaftar di BEI tahun 2013-2015 & 420 \\
\hline Perusahaan yang tidak melaporkan laporan tahunan selama tahun 2013-2015 & 42 \\
\hline $\begin{array}{l}\text { Perusahaan yang tidak menyajikan informasi terkait jumlah rapat komite audit selama } \\
\text { tahun 2013-2015 }\end{array}$ & 93 \\
\hline Perusahaan yang menggunakan mata uang asing dalam laporan keuangan & 84 \\
\hline Jumlah sampel penelitian & 201 \\
\hline
\end{tabular}

Sumber: Data sekunder yang diolah, 2016

\section{Statistik Deskriptif}

Analisis statistik deskriptif memberikan gambaran atau deskripsi suatu data yang dilihat dari nilai rata-rata (mean), standar deviasi, varian, nilai maksimun, dan nilai minimum (Ghozali, 2013). Analisis deskriptif digunakan untuk memberikan gambaran dan deskripsi variabel-variabel yang digunakan dalam penelitian ini.

Tabel 2

Statistik Deskriptif

\begin{tabular}{|l|c|c|c|c|c|}
\hline & $\mathrm{N}$ & Minimum & Maximum & Mean & Std. Deviation \\
\hline DACC & 201 & .0000488 & 1.0552355 & .076981040 & .0986991654 \\
\hline AAC & 201 & 0 & 1 & .85 & .357 \\
\hline AE & 201 & 0 & 1 & .44 & .498 \\
\hline AAC_AE & 201 & 0 & 1 & .38 & .486 \\
\hline ROA & 201 & -.16048 & 1.15429 & .0875275 & .13533030 \\
\hline Lev & 201 & .03723 & 3.02909 & .4637573 & .37013059 \\
\hline Size & 201 & 10.09 & 17.58 & 13.8120 & 1.49509 \\
\hline Board & 201 & 2 & 10 & 4.27 & 1.752 \\
\hline Valid (listwise) & 201 & & & & \\
\hline
\end{tabular}

Sumber: Data sekunder yang diolah, 2016 
Tabel 3

Keaktifan Komite Audit

\begin{tabular}{|c|c|c|}
\hline Keaktifan Komite Audit & Jumlah & Persentase \\
\hline $\begin{array}{l}\text { Perusahaan yang mengadakan rapat komite audit 4 kali atau lebih } \\
\text { selama 1 tahun }\end{array}$ & 171 & $85 \%$ \\
\hline $\begin{array}{l}\text { Perusahaan yang mengadakan rapat komite audit kurang dari 4 kali } \\
\text { selama 1 tahun }\end{array}$ & 30 & $15 \%$ \\
\hline Total & 201 & $100 \%$ \\
\hline
\end{tabular}

Sumber: Data sekunder yang diolah, 2016

Tabel 4

Audit Eksternal

\begin{tabular}{|l|c|c|}
\hline \multicolumn{1}{|c|}{ Audit Eksternal } & Jumlah & Persentase \\
\hline Perusahaan yang menggunakan auditor Big Four & 89 & $44 \%$ \\
\hline Perusahaan yang menggunakan auditor Non-Big Four & 112 & $56 \%$ \\
\hline Total & 201 & $100 \%$ \\
\hline
\end{tabular}

Sumber: Data sekunder yang diolah, 2016

Tabel 5

Kombinasi Keaktifan Komite Audit dan Audit Eksternal

\begin{tabular}{|c|c|c|}
\hline Kombinasi keaktifan Komite Audit dan Audit Eksternal & Jumlah & Persentase \\
\hline $\begin{array}{l}\text { Perusahaan yang mengadakan rapat komite audit 4 kali atau lebih selama } \\
1 \text { tahun dan menggunakan KAP Big Four }\end{array}$ & 76 & $38 \%$ \\
\hline $\begin{array}{l}\text { Perusahaan yang mengadakan rapat komite audit kurang dari 4 kali } \\
\text { selama 1 tahun dan atau menggunakan KAP Non-Big Four }\end{array}$ & 125 & $62 \%$ \\
\hline Total & 201 & $100 \%$ \\
\hline
\end{tabular}

Sumber: Data sekunder yang diolah, 2016

\section{Hasil Uji Asumsi Klasik}

Hasil uji normalitas menunjukkan hasil distribusi yang normal baik grafik histogram maupun hasil uji one-sampel Kolmogorov-Smirnov yang menunjukkan nilai signifikannya lebih dari 0,05 (Tabel 4.6). Hasil uji multikolonieritas menunjukkan bahwa semua model regresi memiliki nilai VIF yang kurang dari 10 dan nilai tolerance lebih dari 0,10 (Tabel 7). Hasil uji heteroskedastisitas dengan uji Glejser menunjukkan tidak ada satupun variabel yang memiliki hubungan dengan nilai absolut residualnya pada taraf 0,05 (Tabel 8). Hasil analisis regresi diperoleh nilai DW sebesar 1,857. Dengan demikian menunjukkan bahwa model regresi yang digunakan bebas dari autokorelasi.

Tabel 6

Hasil Uji One-Sample Kolmogorov-Smirnov

\begin{tabular}{|l|c|}
\hline & Unstandardized Residual \\
\hline $\mathrm{N}$ & 201 \\
\hline Kolmogorov-Smirnov Z & .654 \\
\hline Asymp. Sig. (2-tailed) & .787 \\
\hline
\end{tabular}

Sumber: Data sekunder yang diolah, 2016 
Tabel 7

Hasil Uji Multikolonieritas

\begin{tabular}{|l|c|c|}
\hline \multirow{2}{*}{ Model } & \multicolumn{2}{|c|}{ Model } \\
\cline { 2 - 3 } & Tolerance & VIF \\
\hline (Constant) & & 1.819 \\
\hline AAC & .550 & 7.548 \\
\hline AE & .132 & 7.849 \\
\hline AAC_AE & .127 & 1.193 \\
\hline ROA & .838 & 1.042 \\
\hline Lev & .960 & 1.862 \\
\hline Size & .537 & 1.730 \\
\hline Board & .578 & \\
\hline
\end{tabular}

Sumber: Data sekunder yang diolah, 2016

Tabel 8

Hasil Uji Glesjer

\begin{tabular}{|c|c|c|}
\hline Variabel & T & Sig \\
\hline AAC & $-0,659$ & 0,511 \\
\hline AE & $-1,484$ & 0,139 \\
\hline AAC_AE & $-0,897$ & 0,371 \\
\hline
\end{tabular}

Sumber: Data sekunder yang diolah, 2016

Tabel 9

Hasil Uji Durbin-Watson

\begin{tabular}{|cc|}
\hline Model & Durbin-Watson \\
\hline 1 & 1.857 \\
\hline
\end{tabular}

Sumber: Data sekunder yang diolah, 2016

\section{Hasil Uji Simultan (Uji F)}

Uji statistik $\mathrm{F}$ pada dasarnya menunjukkan apakah semua variabel independen yang dimasukkan dalam model mempunyai pengaruh secara bersama-sama terhadap variabel dependen, dan untuk menguji apakah model regresi yang digunakan sudah tepat. Apabila nilai profitabilitas lebih kecil dari 0,05 atau jika $\mathrm{F}$ lebih besar dari 1, maka model regresi tersebut fit dan dapat digunakan untuk memprediksi pengaruh variabel independen terhadap variabel dependen. Dari hasil pengujian simultan diperoleh sebagai berikut:

Tabel 10

Uji Signifikansi Simultan (Uji F)

\begin{tabular}{|c|c|c|}
\hline Model & F & Sig. \\
\hline 1 & 9.919 & $.000^{\mathrm{b}}$ \\
\hline
\end{tabular}

Sumber: Data sekunder yang diolah, 2016

Tabel 10 menunjukkan hasil uji $\mathrm{F}$ yang diregresikan dalam penelitian ini. Model regresi dalam penelitian ini memiliki nilai $F$ hitung sebesar 9,919 dan signifikan sebesar 0,000. Berdasarkan tabel diatas dapat dilihat bahwa nilai $\mathrm{F}$ hitung lebih besar dari 1 dan signifikannya kurang dari 0,05 . Hal ini menunjukkan bahwa model regresi dalam penelitian ini memiliki variabel independen secara bersama-sama mempengaruhi variabel dependen dalam setiap model regresi. Model regresi dalam penelitian ini fit untuk menguji pengaruh keaktifan komite audit dan audit eksternal terhadap manajemen laba. 


\section{Hasil Uji Koefisien Determinasi $\left(\mathbf{R}^{2}\right)$}

\section{Tabel 11}

Hasil Uji Koefisien Determinasi

\begin{tabular}{|c|c|c|}
\hline Model & Adjusted R Square & Std. Error of the Estimate \\
\hline 1 & .238 & .086163132501875 \\
\hline
\end{tabular}

Sumber: Data sekunder yang diolah, 2016

Berdasarkan tabel 11 nilai adjusted $R^{2}$ pada model regresi dengan dependen variabel manajemen laba sebesar 0,238 . Hal ini berarti kemampuan variabel independen yaitu keaktifan komite audit, audit eksternal, dan kombinasi keduanya dalam menjelaskan kualitas manajemen laba adalah sebesar 23,8 persen. Sedangkan sisanya 76,2 persen dapat dijelaskan oleh faktor-faktor lain selain variabel independen tersebut. Standar Error of Estimate (SEE) sebesar 0,086163132501875.

\section{Hasil Uji Statistik t}

Tabel 12

Hasil Uji Statistik t

\begin{tabular}{|c|c|c|c|}
\hline Model & B & T & Sig. \\
\hline (Constant) & .135 & 1.970 & .050 \\
\hline AAC & -.042 & -1.836 & .068 \\
\hline AE & -.106 & -3.145 & .002 \\
\hline AAC_AE & .074 & 2.096 & .037 \\
\hline ROA & .369 & 7.506 & .000 \\
\hline Lev & .061 & 3.644 & .000 \\
\hline Size & -.004 & -.779 & .437 \\
\hline Board & -.001 & -.210 & .834 \\
\hline
\end{tabular}

Sumber: Data sekunder yang diolah, 2016

\section{Pengaruh Keaktifan Komite Audit Terhadap Praktik Manajemen Laba}

Berdasarkan hasil uji t yang dilakukan terhadap variabel independen keaktifan komite audit terhadap variabel dependen manajemen laba memiliki nilai t sebesar -1,836 dengan probabilitas $0,068>0,05$. Nilai probabilitas yang berada di atas 0,05 menunjukkan tidak adanya pengaruh yang signifikan keaktifan komite audit (AAC) terhadap manajemen laba (DACC). Kesimpulan yang didapat adalah hipotesis 1 ditolak bahwa keaktifan komite audit tidak berpengaruh signifikan terhadap manajemen laba.

Hal ini menunjukkan bahwa keaktifan komite audit berpengaruh negatif terhadap manajemen laba namun tidak secara signifikan. Dengan kata lain, keaktifan komite audit dapat mengurangi manajemen laba tapi tidak secara signifikan. Kemungkinan alasan yang dapat menjelaskan hal tersebut adalah peraturan yang dibuat Bapepam Nomor IX.I.5 yang menyebutkan bahwa komite audit perlu mengadakan rapat secara berkala paling kurang satu kali dalam 3 (tiga) bulan atau sedikitnya 4 (empat) kali dalam setahun, hanya dijalankan perusahaan sebagai formalitas untuk mematuhi aturan bukan untuk meningkatkan fungsi pengawasan terhadap manajemen. Hal ini didukung dengan adanya bukti yang menunjukkan bahwa sekitar $85 \%$ perusahaan manufaktur yang terdaftar di BEI periode 2013-2015 telah aktif mengadakan pertemuan komite audit sebanyak 4 kali atau lebih dalam satu tahun. Jika dilihat dari kuantitas pertemuan menunjukkan bahwa komite audit telah aktif melakukan pertemuan dan juga mematuhi aturan yang dikeluarkan oleh Bapepam. Akan tetapi, jika dilihat dari kualitas pertemuan mengindikasikan bahwa komite audit belum cukup baik menjalankan fungsi pengawasan terhadap manajemen.

Hasil penelitian ini mendukung hasil penelitian Bedard (2004) yang menyebutkan bahwa tingkat aktivitas komite audit tidak mempengaruhi tingkat manajemen laba sekuat keahlian dan independensi yang dimiliki oleh komite audit. Hasil penelitian Ali (2006) juga menunjukkan bahwa 
tingkat pertemuan komite audit tidak berpengaruh secara signifikan terhadap manajemen laba. Namun, hasil penelitian ini bertentangan dengan penelitian Saleh et al. (2007) yang menemukan keaktifan komite audit berpengaruh positif terhadap manajemen laba.

\section{Pengaruh Auditor Eksternal Big Four Terhadap Praktik Manjemen Laba}

Berdasarkan hasil uji t yang dilakukan terhadap variabel independen audit eksternal terhadap variabel dependen manajemen laba memiliki nilai t sebesar -3.145 dengan probabilitas $0,02<0,05$. Nilai probabilitas yang berada di bawah 0,05 menunjukkan adanya pengaruh yang signifikan dari variabel audit eksternal (AE) terhadap manajemen laba (DACC). Nilai beta sebesar -1,06 menandakan arah koefisien yang negatif. Kesimpulan yang didapat adalah hipotesis 2 diterima bahwa auditor eksternal Big Four berpengaruh negatif signifikan terhadap manajemen laba (DACC). Dengan kata lain, penggunaan auditor eksternal Big Four dapat mengurangi praktik manajemen laba di dalam perusahaan.

Hasil penelitian ini mendukung penelitian Soliman (2014) yang menemukan adanya penggunaan auditor eksternal Big Four berpengaruh negatif secara signifikan terhadap manajemen laba. Auditor eksternal Big Four memiliki insentif yang lebih baik dalam mendeteksi dan mengungkapkan kesalahan pelaporan yang dilakukan manajemen karena klien dapat lebih efektif dipantau oleh auditor eksternal Big Four dan mereka memiliki lebih banyak risiko ketika terjadi kegagalan audit (Bauwhede et al., 2003). Sehingga mereka melindungi reputasinya melalui penghindaran tanggung jawab hukum (Behn et al., 1997). Namun, hal ini bertolak belakang dengan penelitian yang dilakukan Alves (2013) menemukan bahwa penggunaan auditor eksternal Big Four di perusahaan berpengaruh positif secara signifikan terhadap manajemen laba.

\section{Pengaruh Kombinasi Keaktifan Komite Audit dan Auditor Eksternal Big Four Terhadap Praktik Manajemen Laba}

Berdasarkan hasil uji t yang dilakukan terhadap interaksi komite audit dan audit eksternal terhadap manajemen laba memiliki nilai t sebesar 2.096 dengan probabilitas $0,037<0,05$. Nilai probabilitas yang berada di bawah 0,05 menunjukkan adanya pengaruh signifikan dari interaksi kombinasi komite audit (ACC) dan audit eksternal (AE) terhadap manajemen laba (DACC). Nilai beta sebesar 0,074 menandakan arah koefisien positif. Kesimpulan yang didapat adalah hipotesis 3 ditolak bahwa interaksi komite audit dan audit eksternal tidak mempengaruhi manajemen laba (DACC). Dengan kata lain, kombinasi antara keaktifan komite audit dan penggunaan KAP Big Four didalam perusahaan cenderung meningkatkan manajemen laba.

Terdapat beberapa argumentasi yang dapat digunakan untuk menjelaskan hasil penelitian ini bahwa komite audit dan audit eksternal tidak menjadi rekan yang baik dalam menjalankan tugas, peran, dan tanggung jawabnya dengan baik dalam mengawasi dan memantau kinerja manajemen. Kurangnya koordinasi dan informasi antara komite audit dan audit eksternal menjadi faktor penyebab kegagalan mereka dalam mengawasi kegiatan manajemen terkait proses pelaporan keuangan. Namun, hasil ini bertentangan dengan penelitian yang dilakukan Alves (2013) yang menemukan bahwa keberadaan komite audit dan auditor eksternal Big Four secara bersama-sama mengurangi praktik manajemen laba.

\section{Tabel 13}

Ringkasan Hasil Pengujian Hipotesis

\begin{tabular}{|c|c|c|c|c|c|}
\hline Variabel & Prediksi & B & Sig & Keterangan & Keputusan \\
\hline AAC & - & $-0,42$ & 0,68 & Tidak Signifikan & Ditolak \\
\hline AE & - & $-0,106$ & 0,02 & Signifikan & Diterima \\
\hline AAC_AE & - & 0,074 & 0,037 & Signifikan & Ditolak \\
\hline
\end{tabular}

Sumber: Data sekunder yang diolah, 2016

\section{Hasil Uji Variabel Kontrol}

Dalam penelitian ini terdapat 4 variabel kontrol yang digunakan yaitu ROA, Leverage, 
Ukuran Perusahaan (Size), dan Ukuran Dewan Komisaris (Board). Hasil uji t sebagaimana disajikan pada Tabel 12. Pengujian mengenai pengaruh variabel ROA terhadap manajemen laba (DACC) yang didasarkan pada nilai $t$ sebesar 7,506 dengan probabilitas $0,000<0,05$. Nilai probabilitas yang berada di bawah 0,05 menunjukkan adanya pengaruh signifikan dari variabel ROA terhadap manajemen laba (DACC). Pengujian mengenai pengaruh variabel leverage terhadap manajemen laba (DACC) yang didasarkan pada nilai t sebesar 3,644 dengan probabilitas 0,000 < 0,05 . Nilai probabilitas yang berada di bawah 0,05 menunjukkan adanya pengaruh signifikan dari variabel leverage terhadap manajemen laba (DACC). Pengujian mengenai pengaruh variabel ukuran perusahaan terhadap manajemen laba (DACC) yang didasarkan pada nilai t sebesar $-0,779$ dengan probabilitas $0,437>0,05$. Nilai probabilitas yang berada di atas 0,05 menunjukkan tidak adanya pengaruh yang signifikan dari variabel ukuran perusahaan (Size) terhadap manajemen laba (DACC). Pengujian mengenai pengaruh variabel ukuran dewan komisaris (Board) terhadap manajemen laba (DACC) yang didasarkan pada nilai t sebesar $-0,210$ dengan probabilitas $0,834>$ 0,05 . Nilai probabilitas yang berada di atas 0,05 menunjukkan tidak adanya pengaruh yang signifikan dari variabel ukuran dewan komisaris (Board) terhadap manajemen laba (DACC).

\section{SIMPULAN DAN SARAN}

Hasil penelitian ini menunjukkan bahwa keaktifan Komite Audit tidak berpengaruh secara signifikan terhadap manajemen laba. Auditor Eksternal Big Four dan kombinasi Keaktifan Komite Audit dan Auditor Eksternal Big Four berpengaruh signifikan terhadap manajemen laba. Penelitian ini dilakukan hanya pada periode pengamatan selama 3 tahun 2013-2015. Menurut penelitian sebelumnya, dapat disimpulkan bahwa semakin panjang periode penelitian yang digunakan maka semakin baik dan valid hasil analisisnya. Pemilihan objek penelitian hanya menggunakan perusahaan manufaktur yang terdaftar di Bursa Efek Indonesia pada tahun 2013-2015 saja, karena mempertimbangkan jenis perusahaan yang memiliki tingkat akrual yang lebih tinggi. Banyak perusahaan yang tidak melaporkan jumlah pertemuan komite audit dalam laporan tahunannya, sehingga hal ini mengurangi sampel penelitian yang digunakan. Selain itu, terdapat beberapa perusahaan yang tidak mengungkapkan laporan keuangan pada Bursa Efek Indonesia yang menyebabkan data menjadi tidak lengkap dan berkurangnya jumlah objek observasi yang dapat mempengaruhi hasil penelitian

Penelitian ini hanya menggunakan beberapa variabel penelitian saja. Penelitian ini belum menambahkan variabel-variabel lain yang dapat mempengaruhi manajemen laba, seperti keahlian komite audit, independensi komite audit, fee audit, dan struktur kepemilikan. Sejalanan dengan hal tersebut penelitian selanjutnya sebaiknya menggunakan periode yang lebih panjang agar memperoleh jumlah sampel yang lebih besar dan pengukuran terhadap penilaian manajemen laba menjadi lebih akurat. Penelitian selanjutnya diharapkan dapat mempertimbangkan untuk menggunakan objek penelitian seluruh perusahaan yang terdaftar di Bursa Efek Indonesia. Pengukuran selanjutnya diharapkan dapat memasukkan lebih banyak variabel-variabel yang dapat digunakan sebagai fungsi pengendalian manajemen yang berpengaruh terhadap manajemen laba. Misalnya, keahlian komite audit, independensi komite audit, fee audit, dan struktur kepemilikan.

\section{DAFTAR RUJUKAN}

Ahadiat, N. (2011). Association Between Audit Opinion and Provision of Non-Audit Services. International Journal of Accounting and Information Managemnt, 182-193.

Ali, F.H and Rahman, R.A. 2006. "Board, Audit Committee, Culture and Earning Management: Malaysian Evidence." Managerial Auditing Journal Vol. 21, No. 7, pp 783-804

Al-Khabash and Al-Thuneibat. 2009. "Earnings Management Practices from the Perspective of External and Internal Auditors Evidence from Jordan." Managerial Auditing Journal, Vol. 24, No, 1 , pp 58-80

Alves, S. (2013). The Impact of Audit Committee Existence and External Audit on Earnings 
Management Evidence from Portugal . Journal of Financial Reporting and Accounting, Vol. 11, No.2, pp,143-165.

Bapepam-LK. 2012. Keputusan Ketua Badan Pengawas Pasar Modal dan Lembaga Keuangan No. KEP-643/BL/2012 tentang Pembentukan dan Pedoman Pelaksanaan Kerja Komite Audit.

Bruce K. Behn, J. V. (1997). The Determinants of Audit Clients Satisfaction Among Client of Big Six Firms. Accounting Horizons, 7-24.

Chariri, A., \& Ghozali, I. (2003). Teori Akuntansi. Semarang: Badan Penerbit Universitas Diponegoro .

Connie L.Becker, M. L. (1998). The Effect of Audit Quality on Earnings Management. Contemporary Accounting Research, 1-24.

Eldon S. Hendriksen, M. V. (1992). Accounting Theory. United States of America: McGraw-Hill Companies.

Ghozali, I. (2013). Aplikasi Analisis Multivariate dengan Program IBM SPSS 21 (Vol. VII). Semarang: Undip.

Halim, A. (2008). Auditing. Yogyakarta: STIM YKPN.

Heidi Vander Bauwhede, M. W. (2003). Audit Firm Size, Public Ownership, and Firms discretionary Accruals Manajemnt. The International Journal of Accounting.

Hermitasari, R. V. (2016). Pengaruh Komite Audit, Audit Eskternal, dan Dewan Komisaris Terhadap Manajemen Laba.

Indonesia Stock Exchange. "Profil Perusahaan Tercatatat" HYPERLINK "http://www.idx.co.id/id$\mathrm{id} /$ beranda/perusahaantercatat/profilperusahaantercatat.aspx" $\quad$ http://www.idx.co.id/idid/beranda/perusahaantercatat/profilperusahaantercatat.aspx, diakses 4 Agustus 2016.

Jean Bedard, S. M. (2004). The Effect Of Audit Committee Expertise, Independence, and Activity of Aggressive Earnings Management. Auditing: A Journal of Practice \& Theory, 13-35.

Jeffrey Cohen, G. K. (2004). The Corporate Governance Mosaic and Financial Reporting Quality. Journal of Accounting Literature, 87-152.

Jengfang Chen, R.-R. D. (2008). The Effect of Audit Committees on Earnings- Return Association: Evidence From Foreign Registrants in the United States. Journal Compilation, 32-40.

Jensen, M. and Meckling, W. 1976. Theory of The Firm: Managerial Behavior, Agency Costs and Ownership Structure. Journal of Financial Economics 3, 305-360.

Jere R. Francis, E. L. (1999). The Role of Big Six Auditors in the Credibel Reporting of Accruals. Auditing: A journal of Practice \& Theory.

Jiambalvo, J. 1996. Discussion of Causes and Consequences of Earnings Manipulation: An Analysis of Firms Subject to Enforcement by The SEC. Contemporary Accounting Research, Vol. 13 No. 1, pp. 37-47.

Jusup, H. (2001). Auditing. Yogyakarta: STIE YKPN.

Klien, A. (1998). Firm Performance and Board Commitee Structure. Journal of Law and Economics, 275-304.

Lin, J. W., \& Hwang, M. I. (2010). Audit Quality, Corporate Governance, and Earnings Management: A Meta-Analysis. International Journal of Auditing, 57-77.

Krishnan, G. V. (2003). Does Big Six Auditor Industry Expertise Constrain Earninngs Management? Accounting Horizons, 1-16.

Mark L. DeFond, J. J. (1991). Incidence and Circumstances of Accounting Errors. The Accounting Review, 643-655.

Masdupi, Erni. 2005. Analisis Dampak Struktur Kepemilikan pada Kebijakan Hutang dalam Mengontrol Konflik Keagenan. Jurnal Ekonomi dan Bisnis Indonesia. Vol. 20, No. 1; 5769.

Menon, K., \& Williams, J. D. (1994). The Use of Audit Committes for monitoring. Journal of Accounting and Public Policy.

Messier, Glover, \& Prawitt. (2005). Auditing \& Assurance Services. Jakarta: Salemba Empat.

Meutia, Inten. 2004. Pengaruh Independensi Auditor Terhadap Manajemen Laba Untuk KAP Big 
Five dan Non-Big Five. Jurnal Riset Akuntansi Indonesia, Vol. 7, No. 3, h 333-350.

Mohamed M. Soliman, A. A. (2014). Audit Committee Effectiveness, Audit Qualityand Earnings Management: An Emperical Study of the Listed Company in Egypt. Research Journal of Finance and Accounting, 155-166.

Mulyadi. 2009. Auditing. Edisi ke-6. Jakarta: Salemba empat.

Murhadi, W. R. (2009). Studi Pengaruh Good Corporate Governance Terhadap Praktik Earnings Management Pada Perusahaan Terdaftar di Bursa Efek Indonesia.

Pamudji, S., \& Trihartati, A. (2008). Pengaruh Independensi dan Efektivitas Komite Audit terhadap Manajemen Laba.

Patricia M. Dechow, R. G. (1995). Detecting Earnings Management. The Accounting Review, 193225.

Pratiwi, P. dan Purnomo,B.S. 2009. "Pengaruh Earning Power Terhadap Praktek Manajemen Laba." Jurnal Media Ekonomi Vol. 14, No. 1, pp 1-13

Putri, F. A. (2014). Pengaruh Keaktifan Komite Audit dan Keberadaan Auditor Eksternal Big Four Terhadap Manajemen Laba.

Rana Ahmad Baker, A. A.-T. (2011). Audit Tenure and the Equity Risk Premiun: Evidende from Jordan. International Journal of Accounting and Infromation Mangement, 5-23.

Ray Ball, P. B. (1968). An Empirical Evaluation of Accounting Income Numbers. Journal of Accounting Research, 159-178.

Republik Indonesia. 2012. Keputusan Ketua Badan Pengawas Pasar Modal No. 643 Tahun 2012 tentang Pembentukan dan Pedoman Pelaksanaan Kerja Komite Audit. Jakarta.

Riahi, A., \& Belkaoui. (2004). Accounting Theory. Jakarta: Salemba Empat.

Reinushini Chandrasegaram, M. R. (2013). Impact of Audit Committee Characteristics on Earnings Management in Malaysian Public Listed Company. International Journal of Finance and Accounting, 114-119.

Richardson, V. J. (2000). Information Asymmetry and Earnings Management: Some Evidence. Review of Quantitative Finance and Accounting, 325-347.

Saleh, N. M., Iskandar, T. M., \& Iskandar, M. M. (2007). Audit Committe Characteristic and Earning Managemnt: Evidence From Malaysia. Asian Review Accounting.

Sarbanes-Oxley Act. 2002. Public Company Accounting Reform and Investor Protection Act.

Scott, W. R. (2003). Financial Accountinh Theory. Pearson Education Canada Inc.

Scott, W. (Ed.) 2009. Financial Accounting Theory, 5th ed., Prentice Hall, 560p.

Suaryana, A. (2007). Pengaruh Komite Audit terhadap Kualitas Laba. Jurnal Ilmiah Akuntansi dan Bisnis.

Ujiyantho, A., \& Pramuka, B. A. (2007). Mekanisme Corporate Governance, Manajemen Laba, dan Kinerja Keuangan. Simposium Nasional Akuntansi X.

Utami. 2005. "Pengaruh Manajemen Laba Terhadap Biaya Modal Ekuitas" pp 100-116

Xie, B., Davidson, W. N., \& Dadalt, P. J. (2003). Earning Management and Corporate Governance: The Role of Board and the Audit Committe. Journal of Corporate Finance, 295-316. 